\title{
Sukces w nauce języka obcego w świetle podejścia ekologicznego
}

\author{
Success in foreign language learning in the light of an ecological approach
}

\author{
Hadrian LANKIEWICZ \\ Uniwersytet Gdański/ University of Gdańsk \\ E-mail: hadrianlank@interia.pl
}

\begin{abstract}
Resorting to the principles of an ecological approach in doing research (cf. D. Larsen Freeman 1997; C. Kramsch 2002), the sociocultural perspective in understanding language acquisition and the status of English in the present times as well as the recommendations of the Council of Europe regarding autonomization of the process of language teaching, I intend to accentuate problems pertaining to the conceptualization of success in language learning. A crucial element of my considerations is highlighting learner related factors (M. Smuk 2015), including attitudes towards learning a foreign language (W. Wilczyńska 2002) and aspects of critical language awareness (H. Lankiewicz 2015). A theoretical reflection is supported with research offering an insight into the complexity of the notion of success in language learning and its discursive construction conditioned equally by individual attitudes and dominant educational policy. Ultimately, it is demonstrated that personal perception of success is expressed by three narrative modes with the dominating voice expressed via economic language.
\end{abstract}

Keywords: Success, language learning, ecological approach, neoliberalism, narrative study, autonomy in language learning, critical language awareness

\section{Wstęp}

Opierając się na założeniach podejścia ekologicznego w nauce języka obcego (zob. L. van Lier 2004) oraz badaniach fenomenologicznych (zob. C. Kramsch 2002; D. Larsen-Freeman 1997), postulatach podejścia socjokulturowego w akwizycji języków obcych (J.P. Lantolf 2006), statusie języka angielskiego we współczesnym świecie, a także uwzględniając zalecenia Rady Europy w zakresie autonomizacji procesu kształcenia językowego, pragnę zaakcentować problemy związane z konceptualizacją sukcesu w nauce języka obcego w literaturze glottodydaktycznej. Ważnym elementem moich rozważań jest uwypuklenie wartości czynników indywidualnych (M. Smuk 2016), w tym postaw wobec nauki języka obcego (W. Wilczyńska, 2002) oraz aspektów krytycznej świadomości językowej (H. Lankiewicz 2015). Refleksję teoretyczną wzbogaca badanie dające wgląd w złożoność pojęcia „sukces” i ukazujące relację pomiędzy wspomnianymi wyżej obszarami a postrzeganiem własnego sukcesu w nauce języków obcych przez studentów. Badanie pokazuje, że osobiste definiowanie sukcesu ma charakter wyraźnie relacjonalny (słowo rzadko spotykane w języku polskim oznaczające relację, czyli związek i zależność pomiędzy elementami, czy, używając terminu bachtinowskiego (M. Bachtin 1986), dialogiczność wskazującą na kontekstualność słów i poprzednie użycia), gdyż jego postrzeganie wyznaczają dyskursy związane z procesem nauki języka obcego. Jako, że dominującym 
dyskursem w organizacji procesu kształcenia w sensie ogólnym jest dyskurs neoliberalny, nie dziwi więc, że refleksje respondentów badania na temat rozumienia pojęcia „sukces” w nauce języka obcego wykazują dominację tego typu narracji.

\section{Rozumienie pojęcia sukcesu w nauce języka obcego}

Rozumienie pojęcia „sukces” wymaga podstawowego zastrzeżenia, że jest ono nieostre i trudne do zdefiniowania, gdyż jego użycie pociąga za sobą zastosowanie parametrów ewaluacyjnych, które z jednej strony opierają się na subiektywnej ocenie osoby dokonującej ewaluacji (dotyczy to też zasady samoewaluacji), z drugiej jego nieostrość terminologiczna polega na niemożności jednoznacznego określenia punktu przełomowego wyznaczonego kontinuum porażki i sukcesu (rozumienie słowa sukces mieści się w pewnej rozciągłości). Halina Widła (2014: 11) w tym kontekście mówi o problemie określenia wielkości odniesionego sukcesu. Ponadto osiągnięcie sukcesu jest pewnym procesem zachodzącym w czasie odnoszącym się do realizacji zamierzeń lub pragnień, które ulegają ewolucji. Sam sukces jest często stanem zadowolenia niekoniecznie stałym. Permanentność sukcesu w zmieniającej się ponowoczesnej rzeczywistości nie jest nawet chyba czymś czego należałoby oczekiwać. Zapewne, większości z nas znany jest stan ogólnego rozczarowania (nie tak sobie wyobrażaliśmy osiągnięcie celu) po krótkotrwałej euforii, będącej wynikiem realizacji celu. Miara sukcesu zależna jest więc od hierarchii wartości i doświadczeń towarzyszących realizacji zamierzeń. W kontekście szkolnym, dodatkowo dochodzi problem ewaluacji zewnętrznej (nauczyciela lub jednostki pozaszkolnej) oraz samoewaluacji, które bardzo często są rozbieżne.

Pojęcie „sukces” w literaturze glottodydaktycznej pojawia się dość często, co wynika z charakteru samej dziedziny. Wszak, ostatecznie praktycznym wymiarem wszelkiej refleksji teoretycznej tej dziedziny jest przyczynienie się do wspierania procesów akwizycji języka, by zapewnić sukces w opanowaniu nowego języka. Historia lingwistyki stosowanej w wąskim znaczeniu tej dyscypliny ${ }^{1}$ wiąże się $\mathrm{w}$ istocie ze sposobami określenia czynników prowadzących do wyżej wspomnianego celu. Proponowane nowe podejścia i metody do nauki języków obcych najczęściej miały rekompensować dydaktykę językową poprzednich dekad i przybliżać do sukcesu. $\mathrm{W}$ połowie $\mathrm{XX}$ wieku ${ }^{2}$ badacze skupiali się głównie na aspektach przetwarzania da-

\footnotetext{
${ }^{1}$ Powstanie lingwistyki stosowanej jako dyscypliny naukowej kojarzone jest często z systematycznym badaniem metod i procedur w celu usprawnienia nauki języka obcego. Znacząca w tym względzie jest rola Uniwersytetu w Michigan, który jako pierwszy ustanowił instytut kształcący nauczycieli języka angielskiego jako obcego (zob. J. C. Richards and T. S. Rodgers 2000: 8, 45-46), a wydawane tam czasopismo po raz pierwszy użyło zwrotu ,applied linguistics" (lingwistyka stosowana) (zob. W. Grabe 2012). Mimo, że dziś niewiele osób zgodziłoby się z tak wąskim rozumieniem tej dyscypliny naukowej, to jednak pobieżny przegląd zawartości kursów akademickich pozwala stwierdzić, że historyczne rozumienie pojęcia nadal pozostaje w użyciu.

${ }^{2} \mathrm{Na}$ ten okres przypada rozwój dyscyplin naukowych, które za cel swoich badań postawiły zrozumienie procesu akwizycji języka obcego, np. wyżej wspomnianej lingwistyki stosowanej
} 
nych językowych, warunkujących budowanie kompetencji językowej (wymiar psycholingwistyczny), z czasem zaczęto dostrzegać czynniki społeczno-kulturowe, przy czym sam język nie był już postrzegany jako kod czy system gramatyczno-leksykalny, ale raczej jako dyskurs - społecznie ukształtowany system rytuałów komunikacyjnych (wymiar socjolingwistyczny kompetencji komunikacyjnej, w tym kognitywne rozumienie struktur językowych). Z kolei badania nad językiem jako systemem semiotycznym do komunikowania znaczeń, z aktywną rolą użytkownika, skutkowały bardziej redefinicją samego języka jak i rozumienia procesu jego akwizycji. W wielkim uproszczeniu można by rzec, że wyżej nakreślone podejścia przyczyniały się do innego postrzegania sukcesu w nauce języka obcego. Nastąpiło też przesunięcie zainteresowań badaczy nad czynnikami warunkującymi efektywność i skuteczność nauki języka obcego z zewnętrznych (niezależnych od uczącego się) na wewnętrzne (zależne od uczącego się) a samo rozumienie procesu akwizycji językowej przestało być postrzegane jako poszukiwanie uniwersalnych procesów (ang. stability) na rzecz jego kontekstualnej i jednostkowej zmienności (ang. variability).

Zasadniczo, za sukces w nauce języka obcego należy uznać jego opanowanie. Jednak poziom realizacji tego zamierzenia pozostawia szeroką gamę interpretacji. Dla przykładu, możemy wziąć osobę, która opanowała język angielski na podstawowym poziomie komunikacyjnym i jest z tego dumna, ale jej kompetencję w zakresie każdego aspektu językowego prowadzącemu kurs nauczycielowi, jak i przeciętnemu użytkownikowi języka angielskiego jako obcego trudno byłoby uznać za sukces. Z drugiej strony można wziąć bardzo ambitnego studenta, studiów filologicznych, posługującego się biegle tym językiem, a jednak dalekiego od samozadowolenia. Przytoczone exemplum nie ma charakteru czysto teoretycznego, każdy nauczyciel mógłby z pewnością przytoczyć szereg własnych przykładów. Z powyższego wynika, że interpretacja sukcesu w warunkach szkolnych zależy od osób organizujących i nadzorujących ten proces jak i od samego uczącego się.

W pierwszym przypadku pojęcie sukcesu jest warunkowane osiągnięciem celów pedagogicznych, wyznaczonych programem kursu, w tym docelowego poziomu umiejętności językowych, determinowanego przez tzw. kompetencję komunikacyjną ${ }^{3}$. W tym względzie pomocną dla nauczyciela jak i ucznia (w charakterze samooceny) ma być Europejski system opisu kształcenia językowego (ESOKJ), który niejako operacjonalizuje założenia teoretyczne wynikające z wcześniej wspomnianej kompetencji komunikacyjnej (ujednolicając poziomy i wymagania) w odniesieniu do czterech podstawowych sprawności: mówienia, słuchania, czytania i pisania. Osiągnięcie odpowiednich poziomów biegłości jest wyznaczone programem szkolnych lub w kształceniu akademickim Krajowymi Ramami Kwalifikacji (KRK). W definio-

(zob. J. C. Richards/ T. S. Rodger 2001, ss. ) czy psycholingwistyki (zob. I. Kurcz 2001: 17) oraz glottodydaktyki, a ta ostatnia, zgłębiając proces akwizycji języka obcego, stara się uczynić go bardziej skutecznym (zob. S. Grucza 2007: 16-17).

${ }^{3}$ Przyjmuję, że kompetencja językowa (lingwistyczna) jest składnikiem kompetencji komunikacyjnej, jak wynika to z refleksji teoretycznej (zob. M. Canale/ M. Swain, 1980, M. Canale 1983). 
waniu czynników decydujących o sukcesie lub niepowodzeniu w warunkach szkolnych, nadal aktualna wydaje się publikacja Hanny Komorowskiej (1978), która wyróżnia trzy grupy zmiennych: odnoszących się do samego ucznia, środowiska oraz nauczyciela. Należałoby jednakże zaznaczyć, że wiele z tych zmiennych jest zależnych od innych czynników wpływających na proces nauki języka obcego. Dla przykładu, motywacja wewnętrzna ucznia nie jest stałą, jej intensywność zależy od wielu innych czynników, takich jak stosowana przez nauczyciela metoda i techniki, interakcja z innymi uczniami, dotychczasowe odczucie sukcesu i satysfakcja z nauki (zob. M. Ebata 2008), itp. Wszelkie badania w zakresie sukcesu w nauce języka obcego mieszczą się w formacie wyznaczonym lata temu przez publikację Hanny Komorowskiej. Refleksja nad procesem akwizycji uszczegółowiła jednak ilość zmiennych. I tak, dla przykładu podejście strategiczne do nauki języków obcych (zob. R. Oxford 1990) wzbogaciło dydaktykę językową o pojęcie strategii, jako sposobu nauczania/ uczenia się języka mającego zwiększyć możliwość odniesienia sukcesu w nauce języka obcego. Jak zaznaczają niektórzy badacze, strategie uczeniowe, czy komunikacyjne w nauce języka obcego trudno jest od siebie odróżnić, jeśli przyjmie się komunikacyjny charakter nauki języka obcego jako „wspólnych negocjacji wokół form i poszukiwań znaczeń języka docelowego" (S. Piotrowski 2013: 119). Ogólnie rzecz biorąc cytowany autor zaznacza, że założenie jakoby trening strategiczny miał pomóc uczniom mającym problemy z nauką języka oraz, że mniej skuteczny uczeń może przejąć strategie bardziej skutecznego było błędne (ibid.: 210). Jednocześnie, zdaniem Mirosława Pawlaka (2011), trudne jest jednoznaczne ustalenie kierunku zależności pomiędzy sukcesem a wykorzystaniem strategii przez uczących się języka obcego. W kontekście tych badań, nie jestem tak optymistycznie nastawiony do możliwej mierzalności sukcesu jak Halina Widła (2014: 20). Autorka próbuje wskazać kierunek operacjonalizacji zmiennych dotyczących sukcesu w glottodydaktyce za pomocą rygorów naukowych związanych ze stosowaniem odpowiedniej metodologii oraz właściwego pozyskiwania, gromadzenia i prezentowania danych. Czynnik ludzki, o którym mówi $\mathrm{H}$. Widła, jest w zasadzie tym podstawowym, wpływającym na nieprecyzyjność wszelkich badan. Dodatkowo na kształt badania wpływają czynniki wywiedzione z mechaniki kwantowej pod nazwą zasady nieokreśloności Heisenberga. Płynność i wielowymiarowość jako cecha konstytutywna sukcesu sprawia, że jest równie nieuchwytny, a jego pomiar glottodydaktyczny (pozornie obiektywny) może dodatkowo nie komutować ${ }^{4} \mathrm{z}$ odczuwaniem osobistym uczącego się.

W drugim przypadku, stan odczuwania sukcesu zależy od wyznaczonych sobie celów i prezentowanych postaw wobec nauki języka obcego (zob. W. Wilczyńska 2002, A. Surdyk 2005, A. Kitowska/ H. Lankiewicz 2015). Mimo tego, że czynniki indywidualne (osobowościowe) są także uwzględnione w cytowanej wyżej publikacji H. Komorowskiej, to jednak zmiana paradygmatu edukacyjnego $\mathrm{z}$ komunikacyjnego na autonomiczny uwypukliła znaczenie tej grupy zmiennych w przejmowaniu przez ucznia kontroli nad procesem uczenia się języka obcego. Skupienie się na uczniu w

${ }^{4}$ Pojęcie z zakresu fizyki kwantowej odnoszące się nieprzemienności działania dwuargumentowego (Y. Kroyan et al. 2013: 16), zob. także zastosowanie teorii chaosu i kompleksowości w badaniu akwizycji językowej (D. Larsen-Freeman 1997). 
organizacji procesu dydaktycznego i autonomizacja nauki języka obcego wymaga aktywnej partycypacji ucznia na każdym etapie: ustalania celów, treści, wyborze metod, ewaluacji postępów (H. Holec 1981) i uzależnia sukces od własnego zaangażowania oraz kontroli nad własnymi procesami poznawczymi (P. Benson 2001) i metapoznawczymi, rozumianymi jako wiedza o sobie jako uczniu i procesie uczenia się (A. Wenden 1995: 185). Posługując się pewnym uproszczeniem można by rzec, że osiągnięcie sukcesu w nauce języka obcego w dużej mierze zależy od samego ucznia, co z kolei nie zwalnia nauczyciela z odpowiedzialności za organizowanie tego procesu i zwiększanie jego skuteczności choćby poprzez trening strategiczny, pokazujący uczniowi mniej skutecznemu (zobrazuję to metaforycznie), że zupy nie należy jeść widelcem, jeśli chcemy szybko zaspokoić głód. Problem z taką konceptualizacją sukcesu ucznia polega na tym, że rzeczywista organizacja instytucjonalnego procesu kształcenia, w tym językowego, w znacznej mierze odbiega od wspierającej ją refleksji teoretycznej. Ponadto, dzięki procesom globalizacyjnym, radykalnej ewolucji ulega cel, do którego dążymy, mianowicie sam język, jego stan, status, funkcja itp. Uwagi te w znacznej mierze odnoszą się do języków o charakterze pluricentryczym, które nie mają jednego paradygmatu kulturowego. Pozycja języka angielskiego jest tu najlepszym przykładem, nie bez kozery mówi się w tym kontekście o kulturowo neutralnym lingua franca (M.A. Kayman 2004) lub też o śmierci mówcy natywnego (T. Paikeday 1985). Takie widzenie języka redefiniuje nie tylko cele nauki, ale inaczej pozycjonuje samego uczącego się. Wynika stąd, że przynajmniej w zakresie nauki tego języka jako obcego, chociaż dalsze refleksje w tym artykule nie ograniczają się tylko do języka angielskiego, sukces wymaga uwzględnienia perspektywy pokazującej wielowymiarowe relacje pomiędzy uczącymi się podmiotami i tym, co zamierzają opanować. Taki wgląd oferuje właśnie podejście ekologiczne do nauki języka obcego.

\section{Sukces w nauce języka w świetle metafory ekosystemu}

Podejście ekologiczne do nauki języka obcego, w zasadzie określił Leo van Lier (2004) w swojej doniosłej publikacji z ekologią w tytule, w której połączył założenia ekolingwistyczne, rozważania z zakresu semiotycznej aktywności człowieka oraz teorie uczenia się odwołujące się do udziału własnego ja (jaźni) i tożsamości człowieka. W ten sposób zbudował autorski model, dla którego, na podobieństwo funkcjonowania ekosystemu, najważniejszym elementem są wzajemne zależności czynników składowych procesu uczenia się, głównie interakcje w jakie wchodzi uczący się języka z kontekstem językowym na poziomie społecznym, fizycznym i symbolicznym oraz podmiotowość użytkownika - ang. agency (L. van Lier 2010).

Podmiotowość ucznia sprawia, że rezultat nauki jest zależny w głównej mierze od niego samego i jakości interakcji w jakie wchodzi. Takie podejście jest kompatybilne $\mathrm{z}$ autonomizacją procesu nauki języka w kształceniu zinstytucjonalizowanym. Ważnym elementem sukcesu nauki języka w szkole jest więc zapewnienie warunków umożliwiających realizację założeń wynikających z autonomii ucznia. Dla L. van Lier autonomia koreluje ze świadomością i autentycznością w interakcji na lekcji języka 
obcego (1996). Ponadto odnosząc się do krytycznego ${ }^{5}$ (w znaczeniu relacji władzy i wiedzy) wymiaru podejścia ekologicznego, L. van Lier (2004) autonomię rozpatruje w kontekście takich cech charakterystycznych dla proponowanej przez siebie orientacji badawczej i pedagogicznej, jak wartość i jakość. Podczas, gdy pierwszy termin podkreśla aksjologiczny charakter „robienia nauki”, jak i prowadzenie działalności pedagogicznej w oparciu o wartości moralne i etyczne, drugi akcentuje jakość edukacji poprzez zapewnienie podmiotowości ucznia i nietraktowanie go jako elementu systemu ekonomicznego, czy tzw. homo docilis, jak określiłby to M. Foucault (1977) (zob. L. van Lier 2005: 17).

Podejście ekologiczne, a zwłaszcza jego aspekt krytyczny poddaje w wątpliwość założenia neoliberalnej polityki oświatowej, które wymuszają postrzeganie ucznia w wymiarze wyników testowych w imię standaryzacji i rozliczalności - accountability. W tym sensie perspektywa ekologiczna stanowi przeciwwagę dla komercjalizacji procesu kształcenia (L. van Lier 2004: 17), zgodnie z zasadami wolnego rynku. Osobiście, neoliberalną myśl w jej głębokiej strukturze polegającą na tym, że jednostka przejmuje inicjatywę nad własnym życiem i odpowiedzialność za własne wybory (H. Shin and J.S. Park 2016: 444), widzę jako pozornie spójną z zasadą autonomizacji procesu kształcenia (H. Lankiewicz 2017). Komercjalizacja procesu kształcenia, w tym językowego sprawia, że regulacje prawne jak i praktyki pedagogiczne poddane są zasadom neoliberalnego zarządzania ekonomicznego, dla którego najważniejszy jest mierzalny wynik sukcesu, przy jednoczesnym żonglowaniu słownictwem z zakresu autonomizacji procesu kształcenia językowego. Należy jednak zaznaczyć, że autonomia jako refleksja pedagogiczna i zasada neoliberalna są pojęciami niewspółmiernymi. Wykorzystywanie tego pojęcia przez dyskurs neoliberalny sprawia, że staje się bardziej sposobem kontroli niż wyzwolenia. Tak więc to, co pozornie miało dawać wolność i władzę, w rezultacie jest elementem hegemonii, jakkolwiek by ją pojmować, za Antonio Gramsci (1971/ 1991), czy za Michel Foucault (1991). Zgodnie z obowiązującym dyskursem neoliberalnym jednostka ma być odpowiedzialna za wybory i ciągle przystosowywać się do zmieniających się warunków rynku, przy czym to rząd zbiera owoce tego procesu. W rzeczywistości, wolność wyboru jest ograniczona nieintencjonalnymi warunkami rynkowymi (zob. A. Vercelli 2017). W tym kontekście, Hyunjung Shin (2016: 515) ukazuje w jaki sposób zasada przejmowania odpowiedzialności za własne kształcenie językowe przyczynia się to utrzymania istniejącej nierówności społecznej. Stąd wnoszę, że bezkrytyczne stosowanie zasad autonomizacji do procesu kształcenia językowego, bez uwzględnienia szerszego kontekstu społecznego, może w efekcie służyć jedynie jako instrument wzmocnienia ideologii neoliberalnej (H. Lankiewicz 2017), przy zaprzepaszczeniu istotnych wartości pedagogicznych.

By uniknąć powtórzeń argumentów wyłożonych w mojej publikacji analizującej relacje autonomii i neoliberalizmu (zob. H. Lankiewicz 2017), zaznaczyć należy, że

\footnotetext{
${ }^{5}$ Wykładając podstawy podejścia ekologicznego do nauki języków obcych L. van Lier (2004: 12-20) wykazuje jego derywację społeczno-kulturową, czy też inaczej społeczno-konstrukcjonistyczną (P.J. Lantolf 2000: 155), jednakże elementem, który wyraźnie je oddziela jest wymiar krytyczny w rozumieniu tzw. frankfurckiej Szkoły Krytycznej.
} 
sukces w pojęciu neoliberalnym ${ }^{6}$ odnosi się najczęściej do wyników testów językowych w kontekście realizacji efektów kształcenia. W zasadzie na każdym etapie kształcenia określanie efektów jest dokonywane a priori (wynikają one z podstawy programowej lub KRK dla szkolnictwa wyższego) i/ lub z realizacji standardów. Autonomia ucznia czy studenta, jest ograniczona zaledwie do sposobu ich osiągania (autonomia reaktywna, zob. P. Benson 2001: 99). Nawet założenia punktów ETCS, są jedną wielką iluzją (ani nie są one transparentne, ani nie dają możliwości skrojenia programu przez studentów wg własnych zainteresowań). Sukces jest więc mierzony założeniami pozostającymi poza kontrolą studenta, wbrew zasadzie przejmowania odpowiedzialności za własny proces nauki języka obcego.

Zaryzykuję tezę, że postrzeganie sukcesu jest nadal w dużej mierze warunkowane czynnikami pozostającymi poza zasięgiem rzeczywistych preferencji studenta. Wszelkie ankiety ewaluacyjne odnoszą się raczej do określenia zadowolenia z przebiegu kursy i prowadzącego nauczyciela (jego w istocie testują i dyscyplinują, na sposób komercyjny - zadowolenie klienta), niż do określenia stopnia indywidualnie pojętego sukcesu. Jak trafnie zauważa Halina Widła (2014: 17) ankiety satysfakcji z prowadzonych zajęć na uczelniach wyższych nie uwzględniają faktu, że student pozyskuje wiedzę nie tylko na zajęciach. Domniemam, że chodzi tu o to, że prowadzący ma sygnalizować kierunki i możliwości jej pozyskania, zgodnie z zasadą autonomizacji procesu kształcenia.

Współcześnie urynkowienie edukacji sprawia, że także nauka języków obcych nie jest postrzegana jako część ogólnie pojętego procesu rozwoju intelektualnego (na sposób humanistyczny), tak więc samej nauce języka nie przypisuje się większych wartości, najważniejszy jest odniesiony sukces, pozornie obiektywnie mierzony po ukończeniu danego etapu nauki języka obcego, kompetencją językową/ komunikacyjną. W rzeczywistości, warunki rynkowe w szkolnictwie wyższym sprawiają, że sama umiejętność porozumiewania się w języku obcym jest już uznawana za sukces ${ }^{7}$. Tu dochodzimy do kolejnej, podstawowej zasady podejścia ekologicznego - jakości, którą L. van Lier (2004: 12) kontrastuje wyraźnie z rozliczalnością (accountability). Standardowe testy porównuje do muszli na brzegu, które mówią nam, że jest jakieś życie w oceanie, ale na ich podstawie nie jesteśmy w stanie pojąć jego natury i bogactwa form życia. Nauczanie pod testy, wymuszone przez politykę neoliberalną skutkuje właśnie takim efektem. Ani nauczyciel nie ma wglądu w kompetencję

\footnotetext{
${ }^{6}$ Podczas konferencji „sukces w glottodydaktyce”, 20-22 czerwca 2013, prof. Elżbieta Zawadzka-Bartnik wygłosiła wykład plenarny dokonując analizy pojęcia sukces w znaczeniu neoliberalnym i humanistycznym. Niestety, w konferencji nie uczestniczyłem, tom pokonferencyjny nie zawiera tego wykładu, nie udało mi się go namierzyć przy pomocy dostępnych wyszukiwarek zasobów bibliotecznych. Stąd moje użycie i interpretacja tych terminów nie odnosi się w żaden sposób do wspomnianego wykładu.

${ }^{7}$ Krytyka wpływu neoliberalizmu na naukę języka odnosi się np. do takich haseł jak nadmierne przywiązanie do podejścia komunikacyjnego, co jest odbiciem postmodernistycznej „oracy” (przewagi słowa mówionego) (N. Fairclough 1992: 33), bezrefleksyjnego treningu sprawnościowego (B. Urciuoli 2010), inflacji ocen (Ch. Cooper 2009: 206) itp.
} 
ucznia, ani uczeń nie uzyskuje podstaw do rzetelnej samooceny własnych kompetencji.

Autonomia w nauczaniu języka obcego pociąga za sobą także konieczność bardzo indywidualnego rozumienia pojęcia sukcesu. Jednak, by wysokie poczucie własnej wartości nie prowadziło do nadinterpretacji własnych osiągnięć, wymagane jest wykształcenie u osób uczących się języka wysokiego poziomu samowiedzy, w tym komponentu samooceny (zob. M. Smuk 2014: 25). Znajomość samego siebie wydaje się być elementem dodanym procesu kształcenia językowego w sensie humanistycznym (wszak studia, uczenie się czegokolwiek, to nie tylko zdobywanie wiedzy, ale także poznawanie samego siebie). Misją procesu glottodydaktycznego, jako wartości dodanej jest, jak określa to ESOKJ (2003: 22), „kształtowanie pewnych cech osobowości w trackie nauki języka jednego lub kolejnych języków, można także kształtowanie postawy uznać na jeden z celów nauczania”. Dlatego też w autonomizacji procesu kształcenia językowego, coraz częściej wskazuje się na wartość cech indywidualnych uczniów. Maciej Smuk (2016) postanowił zoperacjonalizować pojęcie savoir-être w ramach procesu glottodydaktycznego i ostatecznie zaproponował by zespół czynników indywidualnych „o charakterze kognitywnym, afektywnym czy społecznym” odzwierciedlony w „określonym modus vivendi uczniów, na płaszczyźnie uczenia się języków obcych i komunikowania się w językach obcych" (M. Smuk 2016: 11) uznać za kompetencję, Autor postuluje, że samoświadomość różnic indywidualnych i umiejętne czerpanie z ich zestawu ma wpływ na stan wiedzy (savoir), jej praktyczne wykorzystanie (savoir-faire), a także na sposoby jej zdobywania (savoir-apprendre) (M. Smuk 2016: 58-59). W ten sposób savoir-être uznana zostaje za kompetencję transwersalną - „superkompetencję", warunkującą wszelkie zachowania uczącego się języka obcego. W tej perspektywie, definicja sukcesu w nauce języka staje się pojęciem dość subiektywnym, uzależnionym od osobowości, przekonań, emocji itp.

$\mathrm{Na}$ ocenę własnego sukcesu w nauce języka obcego wpływa niewątpliwie także świadomość językowa (wiedza metajęzykowa), a zwłaszcza krytyczna świadomość językowa (N. Fairclough 1992), która, jak osobiście postuluję (zob. H. Lankiewicz 2015), przekłada się na odpowiednie zdefiniowanie celów nauki jak i sposobów ich realizacji. Bez wątpienia poziom krytycznej świadomości językowej, prócz wiedzy (w tym metajęzykowej) i doświadczenia, zależy także od cech osobowościowych.

\section{Założenia badawcze}

Oryginalnie celem mojego badania było określenie przejawów indywidualnego rozumienia pojęcia sukcesu w nauce języków obcych przez studentów języków obcych i, o ile to możliwe, zidentyfikowanie obszarów oddziaływania (przyczynowo-skutkowych) dla sposobu bycia ucznia/ użytkownika języka obcego. Moim przedsięwzięciem nie zamierzałem badać wagi i wpływu czynników sukcesu i niepowodzenia $\mathrm{w}$ nauce języka obcego (zob. H. Komorowska 1978) w celu określenia wynikających stąd wskazówek metodologicznych. Ostatecznie, po poddaniu wstępnej analizie próby pilotażowej zadecydowałem, że moim zamiarem będzie zarysowanie subiek- 
tywnego obrazu postrzegania sukcesu w nauce języka obcego przez studentów i określenia, w jaki sposób on koreluje z refleksją teoretyczną w zakresie glottodydaktyki, inspirowanej podejściem opartym na metaforze ekologicznej.

Tak ogólnie postawiony cel badania pytania wynika $\mathrm{z}$ charakteru badania ekologicznego, które korzysta, w pewnym sensie, z metodologii badań etnograficznych mających charakter obserwacyjny. Biorąc jednak pod uwagę dyskursywną konstrukcję rzeczywistości, w sensie semiotycznej aktywności człowieka oraz badając interakcje w sensie społecznym, fizycznym i symbolicznym (zob. L. van Lier 2010) jesteśmy w stanie dotrzeć do jednostek analitycznych, które uwzględniają zarówno całościową jak i fraktalną perspektywę rzeczywistości (zob. D. Larsen-Freeman 1997). Dlatego też ekolingwistyka i ekologiczne podejście do nauki języka posługuje się metodologią socjolingwistyki interakcyjnej, jak analiza dyskursu, analiza konwersacyjna, czy też badania narracyjne. Wykorzystanie w badaniu przesłanki społecznej konstrukcji rzeczywistości podkreśla lokalne, sytuacyjne i etnograficzne rozumienie rzeczywistości badanych podmiotów (C. Kramsch and A. Whiteside 2008: 656) oraz uwzględnia fakt interwencji (interpretacji) badawczej zależnej od podejście teoretycznego (M. Jørgensen and L.J. Phillips 2002: 154), co z kolei ma odpowiadać kryterium trafności ekologicznej (ecological validity), czyli zakresowi w jakim badanie odzwierciedla badane zjawisko w sensie spójności wewnętrznej, raczej niż zewnętrznej (zob. C. Kramsch and S.V. Steffensen 2008: 25).

Ekologiczny charakter badania polega przede wszystkim na jego fenomenologicznym charakterze (zob. C. Kramsch 2002), prezentacji problemu tak, jak się on jawi badanym podmiotom w obrębie prezentowanych przez siebie narracji. Z drugiej strony sytuacyjność badawcza uwzględnia kontekst poszczególnych narracji oraz fakt ko-konstrukcji badania przez badacza (zob. L. van Lier 2004: 168), w postaci dodatkowej narracji (wyjaśniającej), wyjaśniających poprzednie (zob. H. Lankewicz 2015). Rodzaj tej ostatniej narracji trudno przewidzieć przed przystąpieniem do badania, stąd cel badania ekologicznego jest zawsze bardzo ogólny, a hipotezę trudno jednoznacznie zweryfikować, zwłaszcza w badaniu narracyjnym.

Metodologia badawcza przyjęta w tym badaniu odnosi się do danych jakościowych w oparciu o typ badania narracyjnego o charakterze autobiograficznym, które kryje się pod terminem autonarracja. Maciej Smuk (2016: 140) optuje za rozumieniem autonarracji jako niezależnej metody badawczej, która wpisuje się w nurt hermeneutyczny i fenomenologiczny, charakterystyczny dla indukcyjnego i eksploracyjnego typu badań. Zaletami autonarracji są introspekcja, samoobserwacja, autodiagnozy oraz „możliwość uchwycenia subiektywnej perspektywy badanych” (M. Smuk 2016: 145). Z tego względu autonarracja wydaje się doskonale wpasowywać w przedsięwzięte zamierzenie badawcze.

Grupa badawcza dobrana jest według zasady dogodności badawczej (Z. Dörnyei 2003: 72), wybrana na zasadzie dostępności, czyli są to studenci, z którymi miałem bezpośredni kontakt, prowadząc różnego typu zajęcia. Są to studenci Uniwersytetu Gdańskiego (UG) oraz Ateneum - Szkoły Wyższej w Gdańsku, zarówno poziomu 
licencjackiego, drugiego i trzeciego roku, jak i pierwszego roku studiów magisterskich, studiujący na następujących kierunkach: skandynawistyka (27 osób), filologia angielska (19 osób), lingwistyka stosowana ( 25 osób), w sumie 71 respondentów.

Osoby te zostały poproszone o napisanie w ciągu 30 minut niezobowiązującej refleksji własnej na temat: Moje rozumienie sukcesu w nauce języka obcego, gdzie jestem, dokąd zmierzam? Byli także poinformowani, że ich refleksja nie musi być stylistycznie i kompozycyjnie wyrafinowana, ważniejsze są ich własne przemyślenia względem postawionego problemu, a ich narracja będzie podstawą dla badania naukowego, którego celem jest zgłębienie osobistego rozumienia sukcesu przez uczniów w nauce języka obcego.

Grupę studentów pierwszego roku studiów magisterskich skandynawistyki UG potraktowałem pilotażowo by sprawdzić, czy ich narracje zawierają zakładany poziom refleksji nad własnym sukcesem oraz jakiego typu danych mogę oczekiwać. Pobieżna lektura ich prac wykazała, że zamiast oczekiwanej autonarracji uwzględniającej własną biografię językową otrzymałem w wielu wypadkach refleksje nad rozumieniem znaczenia słowa sukces, w znaczeniu teoretyczno-praktycznym. Dlatego też w dalszej części badania zdecydowałem się na małą modyfikację tematu na Mój sukces $w$ nauce języka obcego, gdzie byłem, gdzie jestem, dokad zmierzam?, niemniej jednak narracje $\mathrm{z}$ badania pilotażowego także uwzględniłem w analizach.

\section{Analiza}

Analizie poddano wszystkie 71 autonarracji. Lektura prac miała na celu zidentyfikowanie sposobów rozumienia sukcesu w nauce języków i ich klasyfikację. Inspirowany literaturą przedmiotu, starałem się obracać w zakresie postaw wobec nauki języka obcego (W. Wilczyńska 2002) i wpisać postrzeganie sukcesu w ich ramy. Problem polegał na tym, że nie zawsze narracja pozwalała na ich jednoznaczną klasyfikację, co wynika z ich nierozłącznego charakteru (A. Kitowska/ H. Lankiewicz 2015). Ponadto starałem się skorelować pojęcie sukcesu z fragmentami biografii językowej, samoświadomości uczeniowej i egzystencjalnej savoir-être (M. Smuk 2016), językowej (R. Carter 2003), w tym krytycznej świadomości językowej (N. Fairclough 1992), która może skutkować odpowiednim podejściem do uczenia się i użytkowania języka obcego (H. Lankiewicz 2015) tak, jak ujawniały te elementy autonarracje studentów. Ponownie, niekompletność narracji wymuszałaby zastosowanie zbyt wielkiej ingerencji interpretacyjnej badacza.

Jak to często bywa w badaniach ekologicznych, analiza danych ujawnia często cele nie do końca zamierzone, jeśli w analizie mniejszych fragmentów nie traci się z pola widzenia większej całości, ,szerszego kontekstu, który może tłumaczyć samo pojawienie się danej informacji” (M. Smuk 2016: 138). Balansowanie pomiędzy makro i mikro perspektywą pozwoliło mi wpisać poszukiwane przeze mnie drobne elementy badawcze w szerszą ramę, jaką okazały się prezentowane przez respondentów typy narracji, czyli konteksty wypowiedzi i przypisane im znaczenie.

Poprzez typ narracji rozumiem tu „tożsamość narracyjną”, pojęcie wprowadzone przez Paula Ricoeura (1985) oznaczające schemat narracyjny identyfikowany z typem narracji. M. Smuk (2016: 146) powołując się na D. Burrick (2010: 21) utrzymuje, że 
„tożsamość narracyjna kształtuje się podczas redagowania tekstu i znajduje odbicie w doborze opisywanych wątków, ustanawianiu związków między nimi, a w tym nadawaniu swojemu życiu 'własnej' spójności i sensu (...) z punktu widzenia analizy autonarracji przez badacza nie tyle istotne są relacjonowane zdarzenia, co właśnie tożsamość narracyjna”. Struktura, czy jak proponuje P. Ricoeur (1983) konfiguracja, rozumiana w kontekście introspekcji retrospektywnej, uwydatnia ,zupełną dowolność w doborze opisywanych zdarzeń, poglądów i odczuć, nadawanie im post factum własnej spójności oraz ich komponowanie w całość mającą sens dla autora” (M. Smuk 2016: 134).

Osobiste postrzeganie sukcesu w nauce języka obcego ujawnione w autonarracji jest więc, w pewnym sensie rekonstrukcją opisu sposobów uczenia się, a precyzyjniej, motywów uczenia się i traktowane jest tu jako pochodna doświadczeń biograficznych (zob. A. Jurgiel-Aleksander/ J. Dyrda, 2016), które skutkują dominującym typem narracji, czyli szerszym kontekstem znaczeniowym wyrażonym odpowiednim językiem. Typ narracji jest, jak twierdzą A. Jurgiel-Aleksadner i J. Dyrda (2016: 26) za J. Brunerem (1990) ,nadaniem temu, co oni [respondenci] mówią, sensu poprzez odnalezienie schematu znaczeniowego, który kryje się za uprawomocnieniami dotyczącymi własnego uczenia się w ich biografiach".

Sukces w nauce języka obcego jest opisywany przez moich respondentów za pomocą trzech typów narracji, co można rozumieć jako trzy różne sposoby widzenia znaczenia tego pojęcia w sensie motywacyjnym i świadomościowym. Są to (1) narracja wyrażona komunikacyjną funkcją języka, (2) narracja autonomizująca (savoirêtre), obejmująca elementy krytycznej świadomości językowej oraz (3) narracja przy użycia języka ekonomii. Z racji ograniczeń edytorskich zilustruję je przykładami opatrzonymi krótkim komentarzem. Należy jednak zaznaczyć, że o zakwalifikowaniu poszczególnych refleksji do określonego typu narracji decydowała frekwencja słów przypisywanych danej narracji.

Pierwszy typ narracji charakteryzują słowa takie jak: korzystanie z języka, swobodne komunikowanie się, płynne mówienie, nie bać się mówić, swobodnie wyrażać własne myśli, dogadać się z natywnym itp. Polega on na rozumieniu sukcesu wyrażonym praktyczną znajomością języka do celów użytkowych i świadomością, że opanowanie języka obcego jest uwarunkowane realiami społecznymi, nie zaś abstrakcyjną kompetencją językową, która nie znajduje nawet pełnej realizacji wśród użytkowników rodzimych. Dlatego też możliwość swobodnego porozumiewania się z danym jest identyfikowana z sukcesem. Doświadczenie uczenia się języka sprawia, że jakikolwiek perfekcjonizm jest dla nich pojęciem pustym. Skuteczność komunikacyjna raczej niż kompetencja komunikacyjna stanowią o intensywności sukcesu i poczuciu własnej wartości jako uczniów i użytkowników języka obcego.

Mimo jednak ogólnego przekonania, że wysokie poczucie własnej wartości stanowi o sukcesie edukacyjnym (zob. M. Smuk 2014: 25) i z pewnością ogranicza lęk językowy, mam wątpliwości czy skuteczność komunikacyjna powinna być wyznacznikiem sukcesu na poziomie studiów filologicznych i korelować pozytywnie z samoświadomością uczeniową (savoir-apprendre) oraz właściwą oceną własnej kompetencji komunikacyjnej. Moje obawy w tym zakresie może potwierdzać takt, że aż 7 
osób z tej grupy odnosi pojęcie sukcesu do kompetencji mówcy rodzimego, do niego też porównuje własne sprawności językowe i uznaje ten poziom znajomości języka za ostateczny cel edukacji językowej na poziomie studiów filologicznych. Niżej zamieszczone przykłady ilustrują taką konceptualizację sukcesu w nauce języka obcego:

- ... kiedyś myślatam, że moim największym sukcesem bytoby zdanie egzaminu na thumacza przysieglego. Dzisiaj za sukces uznałabym juz fakt, że swobodnie komunikuje się z druga osoba, nie popetniajac przy tym zbyt wielu błędów językowych ... ;

- Nawet jeśli popetniamy btędy językowe ... to i tak najważniejsze jest zachowanie prawdziwości treści aktu komunikacyjnego ... chcę być autentyczna dla tego, który używa angielskiego jako jezyka ojczystego... ;

- ... znajomość jezzyka z perspektywy praktycznej, nie teoretycznej... wspólczesny język ...taki jakim postuguja się natywni... ;

- Po osiagnięciu pewnego progu można mówić o petnym sukcesie, nikt nie jest perfekcyjny nawet w swoim języku ... ;

- Nie bać się korzystać z języka to właśnie sukces ... .

W drugim typie narracji dominują słowa takie jak: rozwijać się, wyrażać siebie, wtasne potrzeby, nie muszę być jak native, każdy mówi inaczej, każdy język mnie wzbogaca, umieć negocjować znaczenie itp. Należy go uznać za przejaw wysokiej krytycznej świadomości językowej i autorefleksji w nauce i uzusie języka obcego. Respondenci wpisujący się swoimi autonarracjami w ten typ wydają się być niezależnymi (autonomicznymi) użytkownikami języka obcego, nie poddają się samomarginalizacji (H. Lankiewicz/ E.Wąsikiewicz-Firlej/ A. Szczpeaniak-Kozak 2016), nie uznają języka jako własności danej społeczności kulturowej, zwłaszcza w odniesieniu do języków o charakterze pluricentrycznym jak angielski. Znajomość wielu języków widzą jako wartość intelektualną zgodnie z założeniami multikompetencji (V. Cook 1996). Są przy tym krytyczni względem własnej kompetencji językowej, gdyż sukces w nauce języka obcego jest dla nich pojęciem względnym, uzależnionym od czynników społecznych. Sukces ma także wymiar praktyczny (ekonomiczny), ale ten element nie zajmuje dominującego miejsca w narracji:

- Sukces w nauce nie jest osiagany w $100 \%$, zwłaszcza jeśli zna się kilka języków ... ;

- ... nigdy nie osiagnę zamierzonego poziomu, bo brakuje mi znajomości prawa $i$ realiów kulturowych krajów, których języków się uczę ... bytabym naiwna osoba, gdybym spoczęta na laurach i uznata, ze to już koniec nauki ;

- ... nie musze starać się uchodzić za kogoś kim nie jestem ... znajomość kilku języków czyni mnie lepsza, bogatsza intelektualnie niż ,, dobra” znajomość jednego języka ;

- Sukces to połaczenie pasji, nauki, rozwoju. Pomocy innym, poczucie misji, dobrych zarobków oraz niezależności ... .

I wreszcie trzeci typ narracji obfituje w słownictwo typu: znajomość języka to klucz do sukcesu, dziś nie można nie znać angielskiego, języki to gwarancja dobrej pracy, przydatność języka obcego, po co mi cała teoria językoznawcza, mówić jak natywny, to robi wrażenie i przynosi profity, uczyć się języków przydatnych itp. Studenci reprezentujący go uzależniają sukces w nauce języka obcego od poprawy warunków ekonomicznych. Nauka języka ma silny aspekt praktyczny, co wpisuje się w dominujący model kształcenia neoliberalnego. Jest to typ narracji określający sukces 
znacznej części respondentów. Z puli 71 narracji aż w 37 przypadkach dominuje wątek ekonomiczny jako element motywujący i świadomościowy, determinujący ich wybór kierunku studiów oraz określający poziom sukcesu związanego z inwestycją w naukę języków obcych:

- ... Zaczętam uczyć się języków obcych bo chciałam dostać dobra pracę, właściwie już zarabiam na jezzykach...;

- $\quad$... W dzisiejszych czasach aspekt ekonomiczny jest najważniejszy, kto mało zarabia tego się nie szanuje ... dlatego nie uczę się języków mało przydatnych, nie mam czasu na hobby ...;

- Dla mnie zawsze najważniejsze było uczyć się rzeczy praktycznych, z których moge coś mieć ... ;

- ...mój cel to poziom zaawansowany i praca w firmie międzynarodowej... .

\section{Dyskusja}

Postrzeganie sukcesu językowego za pomocą języka ekonomii w zasadzie nie powinno dziwić jeśli weźmie się pod uwagę fakt, ze idee neoliberalne ${ }^{8}$ penetrują także współczesną edukację (zob. M. Holborow 2015), w tym językową (zob. H. Shin 2016). I jak utrzymuje Joanna Rutkowiak (2010) rynkowość edukacji jest rezultatem procesów globalizacyjnych. Nauczanie języka obcego, zgodnie z zasadami neoliberalizmu nastawione jest na kształcenie sprawności, mierzalnych kompetencji, a w zasadzie sprawności językowych (H. Shin 2016) w ograniczonych ramach czasowych, przy czym, zgodnie z zasadami autonomizacji procesu kształcenia, uczeń ponosi główną odpowiedzialność za własny rozwój.

Dumnie dążymy do społeczeństwa obywatelskiego, społeczeństwa wiedzy, gdy tymczasem neoliberalne społeczeństwo wydaje się coraz mniej kompetentne i mniej poinformowane. Krytycy komercjalizacji szkolnictwa pokazują nieadekwatność stosowania zasad rynkowych do działalności edukacyjnej (zob. E. Potulicka 2010). Neoliberalizm nie tylko kształtuje nauczanie języków, ale także staje się ucieleśnieniem idei neoliberalnych (H. Shin 2016: 511). Bezkrytyczne promowanie autonomii w nauce języków obcych może mieć odwrotne skutki od tych zamierzonych przez propagatorów idei centralizacji pozycji ucznia. Małą liczbę narracji autonomizujących proces uczenia się języka obcego można zinterpretować, jako rezultat nauczania sprawnościowego, nawet na poziomie akademickim, w którym, przy okrojonych programach, coraz mniej miejsca przeznacza się na budowanie świadomości językowej czy uczeniowej. W zasadzie ten aspekt nauki języków obcych uwydatniał się w refleksji osób, które rozważają możliwość dalszego rozwoju naukowego.

\footnotetext{
${ }^{8}$ Mimo swojej złożoności terminologicznej (zob. A. Vercelli 2017) pojęcie to najczęściej odnosi się do polityki promocji gospodarki wolnorynkowej w wersji „dzikiego kapitalizmu”, charakteryzującej się zintensyfikowanym konsumeryzmem, utowarowieniem wszelkiej działalności ludzkiej, oraz globalizacją przy jednoczesnym demolowaniu jakiejkolwiek aktywności opiekuńczej państwa nad swoimi obywatelami (zob. D.E. Thorsen/ A. Lie 2007: 2).
} 
Dominacja narracji ekonomicznej w definicji sukcesu w nauce języka obcego jest kompatybilna z rezultatami badań nad rozumieniem uczenia się Alicji Jurgiel-Aleksander i Jolanta Dyrdy (2016). By oddać należną sprawiedliwość, muszę przyznać, że znajomość tych badań pozwoliła mi znaleźć wspólny mianownik dla moich analiz. Cytowane autorki, przywołując myśli znanych reprezentantów szkoły krytycznej, akcentują: za Z. Kwiecińskim (2007), ,że opis uczenia się w języku ekonomii jest pochodną postawy 'odobywatelnienia' i cichej rezygnacji państwa z odpowiedzialności za edukację, która uległa komercjalizacji”, za G.J.J. Biesta (2010), „że przejęcie języka ekonomii do opisu uczenia się powoduje, iż przestaliśmy pytać o to, co znaczy, że edukacja jest dobra, a skoncentrowaliśmy się na tworzeniu warunków (udogodnień) do uczenia się i stosowania jego pomiaru", a za S.D. Brookfield (2005), że podkreśla to „konieczność odbudowywania społecznej wrażliwości” (A. Jurgiel-Aleksander/ J. Dyrda 2016: 32).

Edukacja językowa traci swój potencjał społecznego zaangażowania poprzez np. budowanie kompetencji interkulturowej, czy rozwoju poziomu krytycznej autonomii językowej (P. Benson 1997), która pozwoliłaby zbudować odpowiedzialnego obywatela, świadomego roli języka w budowaniu rzeczywistości, czy transformatywnego intelektualisty (H. Lankiewicz 2015).

\section{Podsumowanie}

Postrzeganie sukcesu w nauce języka obcego w badanej puli okazuje się w małym stopniu zdeterminowane osiągniętymi wartościami akademickimi, czy ogólnym rozwojem intelektualnym. Wyłaniająca się wizja sukcesu jest daleka od tradycyjnego dążenia do osiągnięcia akademickiej perfekcyjności. Mimo to, część studentów zauważa aspekty rozwoju intelektualnego i społecznego nauki języków. Niestety są w wyraźnej mniejszości.

Znaczna część respondentów opisując sukces za pomocą narracji ekonomicznej, wydaje się ulegać dominacji dyskursu neoliberalnego, co jest przejawem jego hegemonii w edukacji akademickiej. W pewnym sensie burzy to moje oczekiwania związane z zainicjowanym projektem. Spodziewałem się, że postrzeganie sukcesu w nauce języka obcego, zwłaszcza na poziomie akademickim, będzie mieniło się wielością subiektywnych oczekiwań i postaw będących wyrazem świadomości językowej i autonomicznego podejścia do nauki języka obcego, cech jakich oczekuje się na tym poziomie kompetencji językowej. Zdumiewa fakt, że studenci studiów filologicznych, w większości wypadków rozumieją swój sukces głównie w kategoriach rynkowych.

\section{Bibliografia}

Bachtin, M. (1986), Estetyka twórczości stownej, tłum.: D. Ulicka, Warszawa.

Benson, P. (1997). The philosophy and politics of learner autonomy, (w:) P. Benson/ P. Voller (red), Autonomy an independence in language learning, London. 18-34. Biesta, G.J.J. (2010), Good education in an age of measurement: Ethics, politics, and democracy, London. 
Brookfield, S.D. (2005), The Power of Critical Theory for Adult Learning and Teaching, New York.

Bruner, J. (1990), Życie jako narracja, (w:) „Kwartalnik Pedagogiczny” 4, 3-17.

Burrick D. (2010), Une épistémologie du récit de vie, (w:) „Recherche Qualitative et Temporalités" 8 (Hors série), 7-36.

Canale, M./ M. Swain (1980), Theoretical bases of communicative approaches to second language teaching and testing, (w:) „Lingwistyka Stosowana/ Applied Linguistics/ Angewandte Linguistik"1, 1-47.

Canale, M. (1983), From communicative competence to communicative language pedagogy. (w:) J.C. Richards/ R.W. Schmidt (red.), Language and communication, London, 2-27.

Carter, R. (2003), Language awareness, (w:) „ELT Journal” 57 (1), 64-65.

Cook, V. (1996), Competence and multi-competence, (w:) G. Brown/ K. Malmkjaer/ J. Williams (red.), Performance and competence and second language acquisition. Cambridge, 57-69.

Cooper, Ch. (2009), Review Essay: Neoliberalism, education and strategies of resistance, (w:) „Journal for Critical Education Policy Studies” 6 (2), 205-217. (URL http://www.jceps.com/wp-content/uploads/PDFs/6-2-11.pdf). [Pobrano 11.08.2017].

Dörnyei, Z. (2003), Questionnaires in Second Language Research: Construction, Administration, and Processing, Mahwah. New Jersey/ London.

Ebata, M. (2008), Motivation Factors in Language Learning, (w:) ,The Internet TESL Journal" Vol. XIV (4), (URL http://iteslj.org/Articles/Ebata-MotivationFactors.html). [Pobrano 11.08.2017].

ESOKJ (2003). Europejski system opisu kształcenia językowego: uczenie się, nauczania, oceniania, Warszawa.

Fairclough, N. (1992), Critical language awareness, London/ New York.

Foucault, M. (1977), Discipline and punish. The birth of the prison, New York.

Foucault, M. (1991), Governmentality, (w:) G. Burchell/ C. Gordon/ P. Miller (red.), The Foucault Effect: Studies in Governmentality, London, 87-104,

Grabe, W. (2012), Applied Linguistics: A Twenty-First-Century Discipline, (w:) R.B. Kaplan (red.), The Oxford Handbook of Applied Linguistics (wyd. 2) (Oxford Handbooks Online), 1-14. (URL http://www.oxfordhandbooks.com/view/10.1093/oxfordhb/9780195384253.001.0001/oxfordhb9780195384253-e-2?print=pdf). [Pobrano 11.08.2017].

Gramsci, A. (1971/1991), Selections from the Prison Notebooks, London.

Grucza, F. (2007), Lingwistyczne uwarunkowania i implikacje glottodydaktyki, [w:] H. Kordela/ T. Zygmunt (red.), Rola językoznawstwa w metodyce nauczania języka obcego, Chełm, 12-24.

Holborow, M. (2015), Language and Neoliberalism, London/ New York.

Jørgensen, M./ L.J. Phillips (2002), Discourse analysis as theory and metod, London. Jurgiel-Aleksander, A./ J. Dyrda (2016), Uzasadnienia indywidualnych sukcesów $i$ porażek życiowych w biografii jako pretekst do rozumienia znaczenia uczenia się. 
Analiza wrażliwa na konteksty, (w:) „Dyskursy Młodych Andragogów” 17, 2534.

Kayman, M.A. (2004), The state of English as a global language: communicating culture, (w:) „Textual Practice” 18 (1), 1-22.

Kitowska, A./ H. Lankiewicz (2015), Defining attitudes towards language learning: Autonomy and second language learning, (w:) „Forum Filologiczne Ateneum” 1 (3), 47-63.

Komorowska, H. (1978), Sukces i niepowodzenie w nauce języka obcego, Warszawa.

Kramsch, C. (red.). (2002), Language learning and language socialization. Ecological perspectives. London/ New York.

Kramsch, C./ S.V. Steffensen (2008). Ecological perspectives on second language acquisition and socialization, (w:) N. Hornberger/ P. Duff (red.), Encyclopedia of language education Vol. 8: Language and socialization, Heidelberg, 17-28.

Kramsch, C./ A. Whiteside (2008), Language ecology in multilingual settings. Towards a theory of symbolic competence, (w:), Lingwistyka Stosowana/ Applied Linguistics/ Angewandte Linguistik" 29 (4), 645-671.

Kroyan, Y./ M. Wojcieszyk/ K. Dulski (2013) Mechanika Kwantowa. Notatki z wykładów Prof. dr hab. Andrzeja M. Olesia. Uniwersytet Jagielloński w Krakowie, 1-24. (URL http://www.kierunki-zamawiane.uj.edu.pl/download/60/Mechanikakwantowa-prac-zbior.pdf). [Pobrano 11.08.2017].

Kurcz, I. (2001), Psychologia języka i komunikacji. Wydanie nowe, Warszawa.

Kwieciński, Z. (2007), Między patosem a dekadencja. Studia i szkice socjopedagogiczne, Wrocław.

Lankiewicz, H. (2017), Is there a place for "sowing" in L2 education at the university level? Neoliberal tenets under scrutiny, (w:) M. Pawlak/ A. MystkowskaWiertelak (red.), Challenges of second and foreign language education in a globalized world. Studies in honor of Krystyna Droździał-Szelest, Heidelberg/ New York/ Dordrecht/ et al. w druku.

Lankiewicz, H. (2015), Teacher language awareness in the ecological perspective: A collaborative enquiry based on languaging, Gdansk.

Lankiewicz, H./ E. Wąsikiewicz-Firlej/ A. Szczepaniak-Kozak (2016), Insights into language teacher awareness with reference to the concept of self-marginalization and empowerment in the use of a foreign language. (w:) „Porta Linguarum” 25, $147-161$.

Lantolf, J.P. (red.) (2000), Sociocultiral theory and second language learning, Oxford.

Lantolf, J.P. (2006), Sociocultural theory and second language learning: State of the art, (w:) „Studies in Second Language Acquisition” 28, 67-109.

Larsen-Freeman, D. (1997), Chaos/ complexity science and second language acquisition, (w:) , Lingwistyka Stosowana/ Applied Linguistics/ Angewandte Linguistik" 18 (2), 141-165.

Lier, L. van (1996). Interaction in the language curriculum: Awareness, Autonomy, Authenticity. London. 
Lier, L. van (2004), The ecology and semiotics of language learning: A sociocultural perspective, Boston.

Lier, L. van (2010), The ecology of language learning: Practice to theory, theory to practice, (w:) „Procedia Social and Behavioral Sciences” 3, 2-6. (URL http:/www.sciencedirect.com/science/article/pii/S1877042810013790). [Pobrano 11.08.2017].

Paikeday. T. (1985), The native speaker is dead! Toronto.

Piotrowki, S. (2013), O strategiach $w$ komunikacji egzolingwalnej $w$ warunkach formalnych, (w:) „Lingwistyka Stosowana/ Applied Linguistics/ Angewandte Linguistik" 8, 117-131.

Potulicka, E. (2010). Pedagogiczne koszty reform skoncentrowanych na standardach i testowaniu, (w:) E. Potulicka/ J. Rutkowiak (red.), Neoliberalne uwikłania edukacji, 177 - 202, Kraków.

Recour, P. (1983), Temps et récit, tom I: L'intrigue et le récit historique, Paris.

Recour, P. (1985), Temps et récit, tom III: Le temps raconté, Paris.

Richards, J.C./ T.S. Rodgers (2001), Approaches and Methods in language teaching. Cambridge.

Rutkowiak, J. (2010), Uczenie się w warunkach kultury neoliberalnej: kontekstowanie jako wyzwanie dla teorii kształcenia, (w:) J. Rutkowiak/ E. Potulicka (red.), Neoliberalne uwikłania edukacji, Kraków, 163-176.

Shin, H./ J.S. Park (2016), Researching Language and neoliberalism, (w:) „Journal of Multilingual and Multicultural Development" 37 (5), 443-452.

Shin, H. (2016), Language "skills" and the neoliberal English education industry, (w:) „Journal of Multilingual and Multicultural Development” 37 (5), 509-522.

Smuk, M. (2014), Poczucie własnej wartości - prognostyk sukcesu w uczniu się, (w:) J. Sujecka-Zając/ A. Jaroszewska/ K. Szymankiewicz et al. (red.), Inspiracja Motywacja - Sukces. Rola materiałów dydaktycznych i form pracy na lekcji języka obcego, Warszawa, 23-33.

Smuk. M. (2016), Od cech osobowości do kompetencji savoir-être - rozwijanie samoświadomości w nauce języków obcych. Lublin/ Warszawa.

Thorsen, D.E./ A. Lie (2007), What is Neoliberalism?, (Department of Political Science University of Oslo. 2000 (WebCT), working paper), 1-17.

Urciuoli, B. (2010), Neoliberal Education: Preparing the Student for the New Workplace, (w:) C. Greenhouse (red.), Ethnographies of Neoliberalism, 162-176, Philadelphia.

Vercelli, A. (2017), Crisis and Sustainability. The Delusion of Free Markets, London.

Wenden, A. (1995), Learner training in context: A knowledge based approach, (w:) ,System” 23 (2), 183-194.

Widła, H. (2014), Mierzalne wykładniki sukcesu-operacjonalizacja zmiennych, (w:) J. Sujecka-Zając/ A. Jaroszewska/ K. Szymankiewicz et al. (red.), Inspiracja Motywacja - Sukces. Rola materiałów dydaktycznych i form pracy na lekcji języka obcego, Warszawa, 11-21.

Wilczyńska, W. (2002), Osobista kompetencja komunikacyjna: między postawa a działaniem, (w:) W. Wilczyńska (red.), Doskonalenie się w komunikacji ustnej, Poznań, 69-83. 